\title{
PATHOGENESIS OF MUCOCELE OF THE FRONTAL SINUS.
}

- As a Pneumatization Anomaly of the Sinuses-

By

T. GOTO, M.D.

\author{
Department of Otorhinology, Nagasaki University School \\ of Medicine, (Director: Prof. Toshiro Goto)
}

Pathogenesis of the mucocele was discussed on the basis of the author's pneumatization theory. The construction of the pneumatic cavities are considered to be divided into two parts, i.e. the canal and the antrum. The Euchstachian tube, the nasofrontal duct and the bronchus correspond to the canal part of the pneumatic cavity.

From the study on the development of the bronchi and the alveoli, the author concluds that the canal part (bronchus) may become atrophic, if the antrum (alveoli) enlarges (emphysema), and on the other hand, the canal part may become hypertrophic and dilate (broncuiectasis), if the antrum becomes apneumatic.

This mechanism can be applied to the relationship of the frontal sinus and its duct. Therefore, in the large frontal sinus the duct may become narrowed and then obliterated.

However, roentgenological study of 12 cases of frontal sinus mucocele indicates that the mucocele of the frontal sinus does not occur only in the large frontal sinuses, but also in the moderate large sinuses, by which the over development of the anterior ethmoidal sinuses were confirmed. Over de. velopment of the anterior ethmoidal sinuses might cause the constriction of the nasofrontal duct: The author emphasises that as one of the etiological factors of mucocele of the frontal sinus the over development of the frontal sinus and the ethmoidal sinus, namely the pueumatization anomaly of the paranasal sinuses, should be considered.

\section{Mucocele の成因についての仮説}

一副鼻腔の発育異常 (含気化異常) として—

$$
\begin{aligned}
& \text { 長崎大学医学部教授 } \\
& \text { 後藤敏郎 }
\end{aligned}
$$

前頭洞 Mucocele が自然口の閉鎖によつて発症する あのであることはほが認められているとみてよいと思 う. 問題はこの Ductus 閉鎖の原因であつて, これに ついては合理的な説明を欠いだっ今では殆んど顧みら れよらとしていない，艺れはこの疾患が珍らしくない疾 患であるというよりも，手術による治癒が難かしくない ためであるら。

私は最近前頭洞の Mucocele の症例で，目ら誩断を 誤つた例を経験した，この例から Mucocele に就て考 えさせられる機会を得，これに，私の続けている巬腔の
Pneumatisation の考方が交文して，この Mucocele の成因や增殖に一つ考え方を持つに至つたので報告する $こ と>L た$.

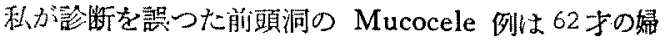
人で，極めて軽い Exophthalmus が見られていた例て あるか゚この例をその後前隻のレ線像を見て Mucocele ではあるまいと思ったのである，その理由は，写真に示 す上らに(図 1)，前頭洞は極めて大きいが，その輸蔀に 弧状の凹凸や隔壁が認められることである.私はMucoceleであれば輪㢌る 円形で規則的なるのであろらと信 
图 1 左前頭洞ムコケーレ 左前頭洞には弧状輪遊と隔壁状突起が認めら 了。

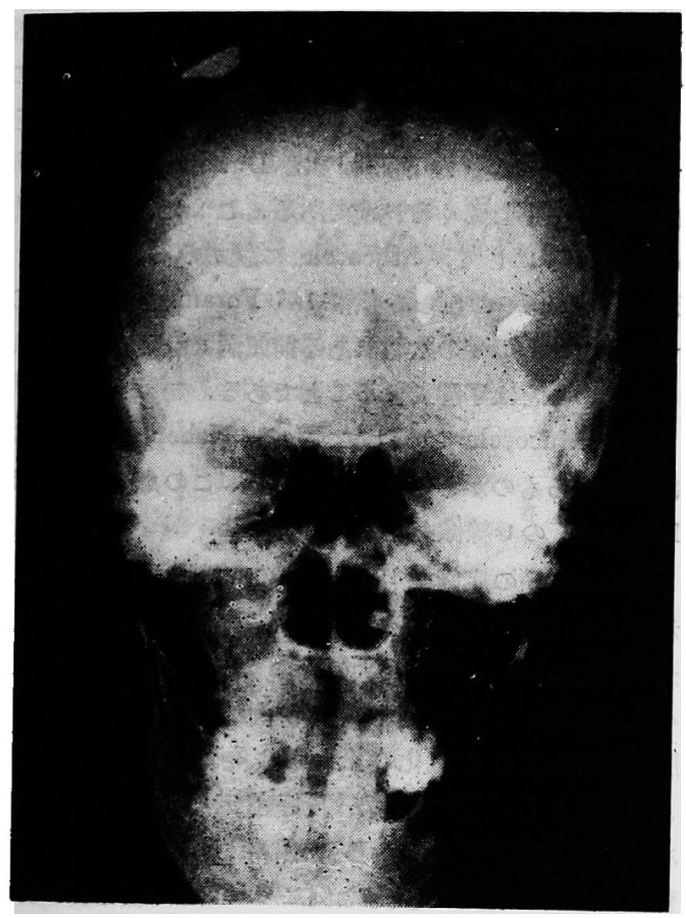

じていた次第であつたが，後にこの例は Mucocele で あることか゚確かめられた。

この例から私は次の 2 つのことを知つた.

(1) Mucocele は極めて発育の良い大きい洞加発泟 すること。

(2) 洞の自然口が閉鎖して Cyste 化してから比較的 に短時日に骨破壊による症状を現らわすこと（骨吸収が 速かであること).

以上の 2 点に就て確かめるとつもに, 前頭洞 Mucocele の成因に就て考察すること〉した.

1) 前頭洞の発育と Mucocele の成立との|関係

Mucocele の成因については，外傷を原因と与る説む あるが，既往症に外傷のない例が多いことから外傷は普 遍的な原因とは考えられない。

洞粘膜の炎症によるとする説は Mucocele の粘膜に は炎症性変化の乏しい例のあること，他の副鼻腔には特 に Sinuitis と呼ばれるほどの変化を欠く例の多いこと， 中畺道粘膜に変化の 少ないこと等の, 事実からも否定で きるし，むしも，Mucocele が粘荧の炎泟の結果から発
症するものであれぱ，当然口の閉鎖によつてはむしろ Empyem になる筈である. 従つて Pyocele の如く粘膜 に炎症性変化の強い例るあるが, 二次的の感染によるも のもあつて, 炎症の先駆をその発症の条件とするものと は考えられ難い。

又, Mucocele に見られる軽い炎症性の变化は骨吸收 に伴う反応性のものと考学ることもできる.

Mucocele を粘液腺より発生したものと見做すには队 面が線毛上皮細胞で被われている—部分的には Metaplasie ああるが一ことから反対できる.

放頭洞 Mucocele がその発育に関連して，その自然 口の閉鎖をきたすに至る機序の説明には，含気腔構成の 基本的問題に遡らなければならない。

含気腔の構成は分析すると小胞形成 Zellenbildung と洞形成 Hoehlenbildung の 2 つの様式の組み合わせか らなつていることを，私はこの種の研究の基本として 屡々唱えてきた，最近になつて含気腔の構成を考皇るに は, もう一つ大きく分けて，管腔部 Canal と空洞部 Antrum との 2 区分に大別して考える必要のあること に気付いた（図2)，小胞形成と洞形成とはこの空洞部 内に拉ける構成である，この管腔部は Mastoidzellen で は Tuba であり, 前頭洞では Ductus nasofrontalis で あり、肺では Bronchien である．上顎洞や笁骨洞では その管腔部が著しく短絔し，一部は鼻道の Recessus の 形を呈するに至つたものであると考劣ると，Nebenhoe: hle もずへて管腔部と洞腔部から成つていると見做すこ とができる。

図 2 a. 管腔部 b. 洞腔部 空膑の構成
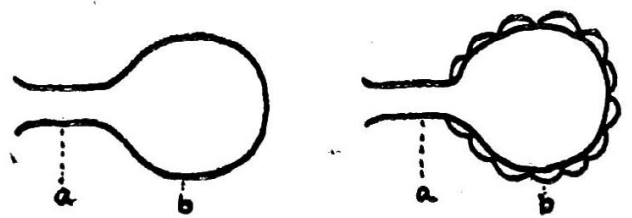

この含気腔の管腔部と空洞部との間に発育の上で相対 的に関保の存在していることを私は肺に打ける実験と観 察12)3)でこれを知ることがでさた。この肺に拈ける Bronchien と Alveolen の関係を Ohr や Naseにま で敖衍することができるものかどうかについては，Ohr や Nase に就て立証のあとでなければならないが，これ 等の含気腔はその構成の上では基本的な椂式が共通して いることから，Bronchien と Alveoren の間に扔ける 
発青上の相祄阙保は，Ohr の Tuba と Mastoidzellen， Nase $の$ Ductus nasof rontalis $と$ Stirnhoehle との間 にも通ずる可能性は多分にあると思うので，Bronchien とAlveolen との間に批いて得られた一つの関係を Ohr

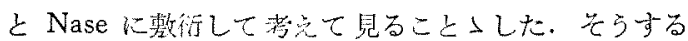
と，今まで解积のできなから Mucocele と Tuben. stenose の成立機序に一つの新しい説明が得られるよう に思引.

肺に扔いて㤎められた一つの Theorie といらのは, rAlveolen み゙維小してくるもBronchien は摭掁し(Bronchiektasie), Alveolen が执大 (Emphysema) すると Bronchien は萎紑する」といらことである。こ机は私 等 (野口，山口等）の研究わら知られたことである。

この関俰任管腔部々空洞部々を持つ形態の器官に共通 的なるのではないかと思呩れることは，筷腔ではない が，整㖡腺 Speicheldruese 汇む認好られる現象である。

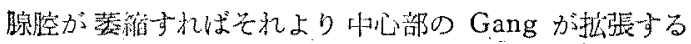

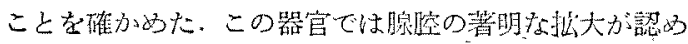
られ触いだけに亲た腺腔の摭大に伴う Gang の維小は 証明できていないがこの関係は必ずしも空腔のみでなく 管腔部之空洞部とを持っている腺様の器官に共酒する むのではないる思っている。

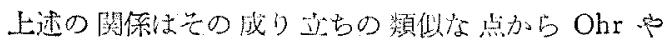

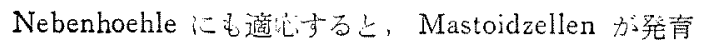

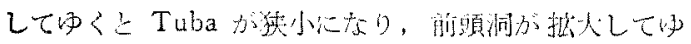

くこDuctus 侇小化することつなる，このことは蔇

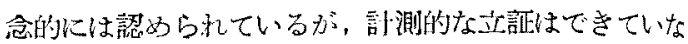
いからその証明は今後のことに予定している. Ductus nasofrontalis やその他の Nebenhoehle の自然口と洞䐦

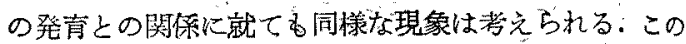
点もまだ帮証の段階に達していないが，この考施から 寸れはは発育の良好な前頭洞では Ductus nasofrontalis は次第に縮小してくるわけである。こ」では Ohr の方 のことは別にして， Mucocele に就てのみ速べると，

Nebenhoehle のうちで目然口が Foramen 状態のの でなくて Ductus の状態沈る前頭洞では先の狭窟のお こり易いことは了䬉できるとである。

次に Mucocele は果して大なる Nebenhoehle のみ に発生するものかということである。この点沈いて性 Mucocele のレ線像を見ることつした。

Mucocele の症例を12例，之のレ線像を見ると表沉 示すように極めて大なる例が 5 例, 中等度の大きさの例 が6例である.この中等大の例のうちには多房性て所謂 小咆化の強いことを示している例が2例：これ等の小 胞化の強い例山含気化の上からは発育の極めて上小例

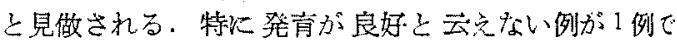
あつた。例数が少ないから結論は络し難いが Pn，の発 青度としては極めて良好な例に Mucocele の発症が多

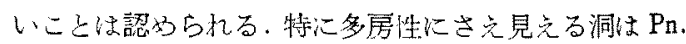
の進化度の高さを示寸るのであるから発育度の政めて良

前㥧洞ムコターレ症例

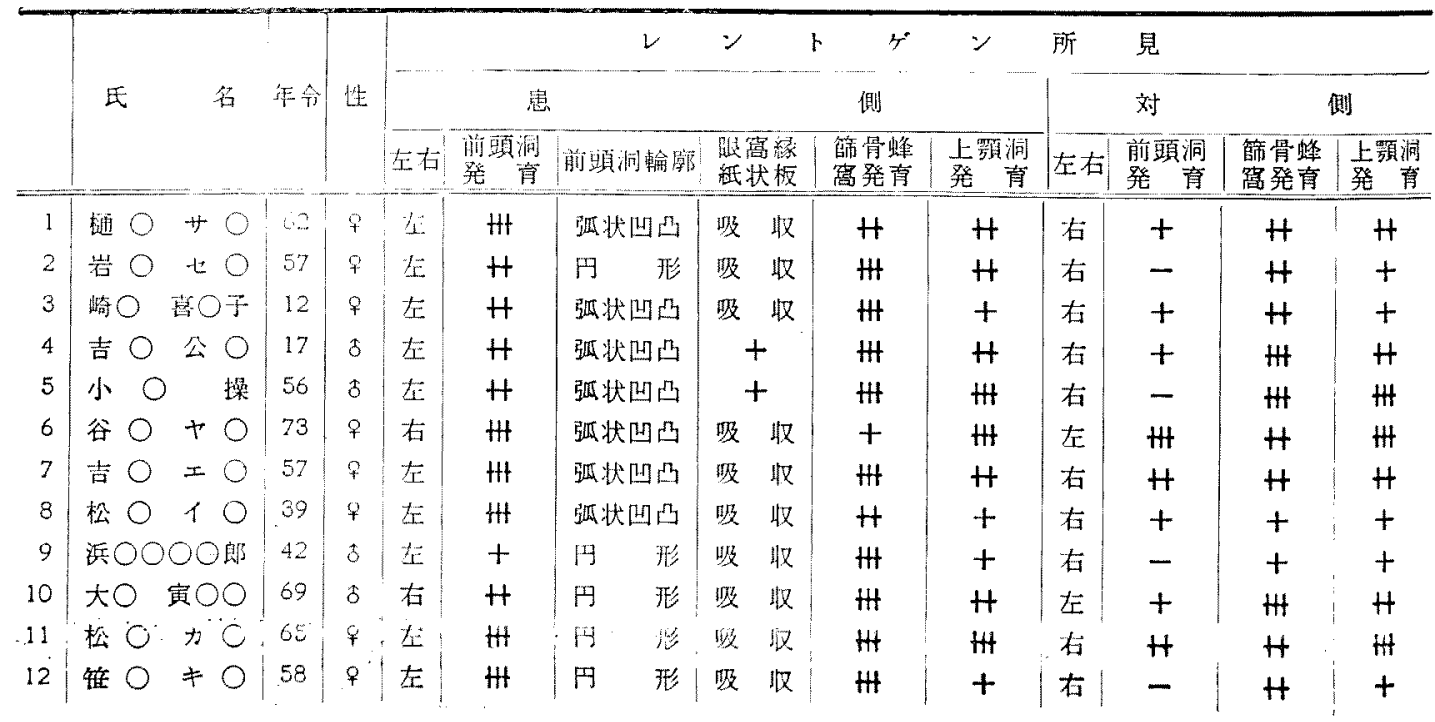


好な例が 13 例中に 7 例といらことになる.

前頭洞の大きさは必ずしも前頭骨の重洎板内へ、の反発 育していないから，その Ductus を持っている例は必ず しも多くない（山口の手術時の観察では前頭型に属する すので 40\%). 私は前頭洞を発育的に節骨型，䇻骨前頭 洞型，前頭節骨型に分けているが，解骨型や前頭篩骨型 のあのでは自然口は Foramen の型で中鼻道に開いてい るから, 斯る例では洞は大であつても狭窄は起り難いこ とつなる. たから洞が大きいからすべて Mucocele を 起すとは限つていないしかし Ductusを持ている前頭 型の例が洞の発育に反比例して Ductus が狭小になり， 自然口の開鎖を起すことは説明できるから，Ductus を持つことる Mucocele を起す重要な条件である.

更に問題は Mucocele のレ線像で知られるように， Mucocele を起す例はすべて大きい洞であるとは限らず に，中等大の例があつて，必ずしる発育が良いと思われ ない例のあることである．斯る例で注意をひくことは節 骨洞の発育が極めて良好であることであつて，特に前頭 解骨蜂集 Fronto-ethmoidale Zellen の過良な発育は前 頭洞底を圧しその Ducts を狭窄することが考㝋られる (図3). 前頭洞底之前節骨蜂案の部位の空腔の状態はそ の相互の発育 (含気化力) の結果によつて決するるので あるから, 前頭洞 Ductus 狭窄の原因を Nebenhoehle の発育異常の一つの現れとして推定することができる. 前頭洞の文に就て考兵ると，Mucocele には洞発育の必 ずしもよくない例が存在し， 刃，洞発育の良好なるのが 必ずしも Mucocele にならない例の存在することから， 前頭洞の発育とつもに監骨洞の発育異常 (含気化過良) を併せ考えることが必要であつて，これによつて上述の Ductus の狭窄についての仮説をたてることができる.

2) Mucocele の增殖に就て

洞の自然口が閉鎖し洞腔が完全な Cyste 化すると洞 は急に增大をはじめるが，これは骨の吸収によるるので あることは云うまでるない。

今写真（図 4) に示すようにその粘膜標本を見ると， 粘膜下に多数の Osteoklasten の浸潤が認められて, 骨 壁は窩状に吸収されている所見が認められる，この例は 洞の極めて大なる例に発生したるのであるが，大なる洞 に発生したもの，即ち大なる Mucocele では骨の吸収 が著明である.この例に示す標本の部位は洞内に突出乙 ている骨櫛 (隔壁) の部分であるが盛んな吰収が行われ ている、この所見よりすれば，骨壁の吸収破壊は短時日 内に進展するものと推測される.この例の他の標本にも
図 3 左前頭洞ムコケーレ 前頭洞は中等大なるも箱骨蜂案の発達極めて良好

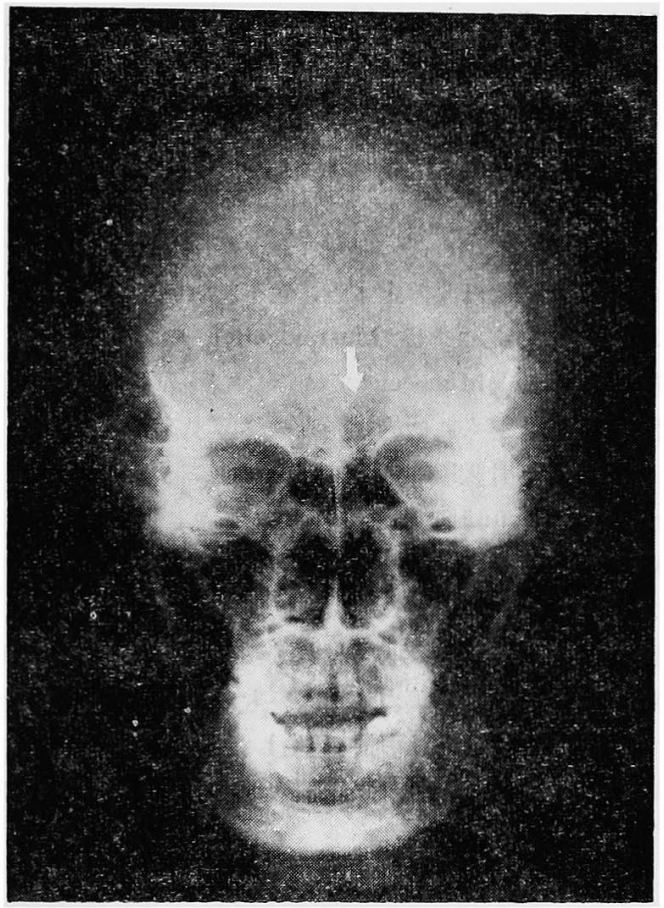

図 4 前頭洞ムコケーレ粘膜（洞内への隔壁状 骨笑起部）破骨練胞の出現による骨吸収 旺盛，反側飞骨增殖認めらる。

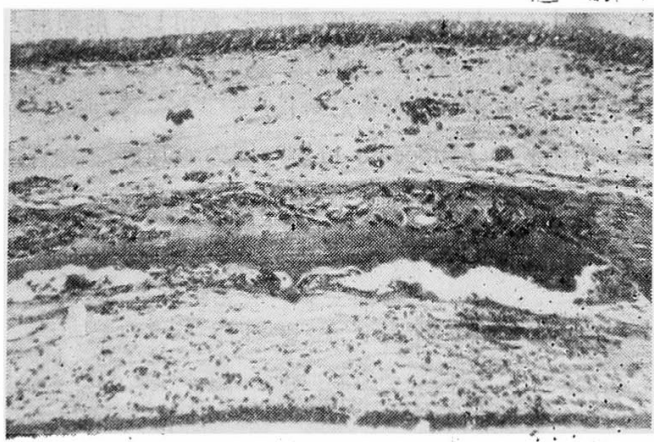

認められるように，この骨の咬収の反対面には弱くはあ

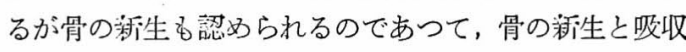
との強さの啹倸が, 後者が前者に勝り, 骨壁の破堷現象 となるのである.

洞の小さい例溌生したもの，即ち小さい Mucocele の鳔本では骨の䀣収も弱いし，澵生も弱い，即ち骨の活 
動が弱いことを示している。

Sinus そのものる，その発育期注骨壁の吸収之新生 が行われ，吸収は Osteoklasten による窩状吸収 Lacunäre Resorption である. 但し, Osteoklasten を認わ ることは困難で極めて稀に発見できるにすぎないから， その吸収は緩慢なものであることは云うまでもない。し かる，生理的な洞の発育で性骨吸收が骨新生を凌鴐する ことはない，しかる，その発育る，盛んな時は幼時であ

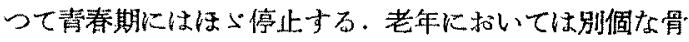
吸收機输によるこ上は Mastoidzellen の発育から推定 されているが，Mucocele では年令関係なく，关の自 然口の閉鎖ととるに病的な発育に移行するるのと思われ る. し小も，骨吸収は生理的の発育期㖊認められるるの と同样沉 Lacunäre Resorption であり，しかるその昅 收速度は極めて速かであることは，骨吸収所見の著明な ことから推定される、これを海江田が行つている上顎の

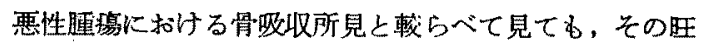

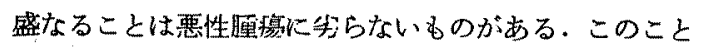
から見て，大なる前頭洞に発生した Mucocele で唗症 状を現らわすまでの時日は比䡌的短いものであることは 了解される。

\section{結語}

前頭洞 Mucocele の成因を 説明するに，含気腔の基 本構成様式艺管腙部と洞腔部とに大別し，著者の，肺胞 と気管校との問に和ける実験から得られた「洞腔部が 执大すれば管腔部は縮小し，洞腔部が 縮小すれれば管腔 部は㹡張する」といら一つの規則を晋衍して前頭洞と Ductus nasof rontalis との間に適応することによつて Mucocele の成立を説明せんとした。

即ち前頭洞の Mucocele は洞の極めて良好な発育に
伴つて起る Ductus nasofrontalis の縮小炕るものひ あろらと推測した。

12 例の Mucocele 例にてこの推測の当否を検討した ところ 5 例において極めて大なる洞を認め，6 例に中等 大のもの，1例儿小なる洞を䛱わたが，これ等の過大で ない例はいずれる節骨洞発育が良好なことから、これ等 の例ては前節骨洞の過大な発育による前頭洞 Ductus の 㹟小化をきたしたものと説明した。

前頍洞 Mucocele は前頭洞及び前籍骨洞の，避良な器 育 (Ueberpneumatisation, over-development) による Ductus nasofrontalis の編小狭窄によるものであうら との仮説を述べた.

更に組織所見に拈ける旺盛な 骨吸収所見（Lacunäte Resorption）とレ線像に扎いて弧状輸廓攴は隔壁状骨壁 の残字することよりみて, 症状の外部へ現机るのは自然 口の閉鎖後比較的に短時日であらうとした，なを，骨の 吸収は大なる前頭洞に速かで小なる洞に発生したものに は緩慢であるとした。

（本䄖文の要旨は1961年7月14口に和计る九州長峰山 口合同地方会にて発表した）

\section{引用自家文献}

1) 後藤敏郎，野口茂樹：含気化と気管支，肺胞の異常 含気化特に気管支払張之脯気腫とに就て，最新医学， $11 ： 2671 ， 1956.2)$ 2) 比関する実験的研究，日本気食会々報，11：64，1960。 3）後藤触郎，山口又郎：虚脱肺胞の再生と気管支の態 度，日本気食会報，11：345，1960。

（原稿到着 $=$ 昭和 36.7 .20 日） 